\title{
International Student Mobility and Turquality Perspective in Higher Education
}

\author{
Meriç Kılınç ${ }^{1^{*}}$, Ali Kurt ${ }^{2}$, Fevzi Rifat Ortaç3 \\ 'Istanbul Aydın University, Communication Faculty, Public Relations And Promotion Department, İstanbul, Türkiye \\ ${ }^{2}$ Gebze Technical University, Kocaeli, Türkiye \\ ${ }^{3}$ Gazi University, Faculty of Economics and Administrative Sciences, Department of Finance, Ankara, Türkiye \\ ORCID: M. Kilıç (0000-0002-2076-6615), A. Kurt (0000-0003-3458-6145), F.R. Ortaç (0000-0002-1839-1420)
}

\begin{abstract}
Purpose: Today, the phenomenon of globalization that directly affects the developments in the world is changing and transforming Higher Education. Internationalization in higher education is one of the critical areas that many countries take into account and develop policies. Increasing the number of international students makes a wide range of contributions to countries. Economic, social, political, academic, and cultural policies are the main factors affecting student mobility. In this study, it is aimed to evaluate the effect of the Turquality program on international student mobility.
\end{abstract}

Design/methodology/approach: In the study, data on international student mobility were evaluated.

Findings: The United States and the United Kingdom, where the higher education system is highly developed, have the highest share in this area, with the contribution of their native language being English. However, the recent anti-globalization developments in these countries have led to a change in the trend of international student mobility, enabling other countries to gain new opportunities. Turkey, with the effect of instability in the hinterland of the country, has achieved a significant rise in the number of international students in recent years.

Discussion: In this study, international student mobility that increases with globalization is analyzed; Turkey's policy in this area and the opportunities provided by the Turquality project to the Higher Education sector are discussed.

Keywords: Branding, Higher Education, Education export, Quality

\section{INTRODUCTION}

The multidimensional effects of globalization have led to the emergence of internationalization in higher education systems. While globalization constitutes the demand of the masses in higher education, internationalization in higher education enables countries and educational systems to develop and implement policies to benefit from this new world order where communication and intercultural interaction is much stronger (Altbach, 1998). It is observed in the literature that four approaches to the concept of internationalization are frequently used as mobility, competence, cultural structure, and process. The mobility approach includes academic movement, field studies, international students, and educational activities related to the curriculum. In the competency approach, actions supporting individual development are taken to the center. In the cultural structure approach, the formation of a culture that promotes the international dimension of the organization

*Yazışma Adresi / Address for Correspondence:

M. Kılıç, Email: merickilinc@aydin.edu.tr

Geliş Tarihi / Received Date: 16.02 .2021

Kabul Tarihi / Accepted Date: 05.08.2021

Doi: 10.26701/uad. 881319 is a matter of concern. The process approach evaluates internationalization within the framework of a process, and it implies a global, intercultural perspective on the essential functions of higher education institutions (Knight, 1994). An increasing number of students across the globe are moving to study at the university level in other countries. This mobility increases competition at the level of states and universities. Evaluating the motivations that direct students to receive education in the countries they are foreign to and the changing factors in student mobility around the world become an issue that needs to be emphasized while developing the educational economy policies of countries (Arkalı Olcay \& Nasır, 2016, p. 288-296).

Choudaha (2017, p.831) states in his study that international student mobility has occurred in three waves since 1999. In the period until 2006, terrorism and financial issues were influential in the preferences, especially with the effect of "September 11". In the following period, financial and academic supports and language issues gained importance. Recently, issues such as the demographic structure of the destination and career opportunities have also gained importance. The three waves of international student mobility show that although the interest in gaining global educational experience re- 
mains strong, the needs and circumstances of students are constantly changing. At the same time, the institutional drivers and foundations for recruiting and retaining international students are constantly evolving. Looking to the future, institutions must innovate not only to increase the enrollment rate of international students, but also to balance with corresponding support services that promote student success. In particular, as competition between destinations and educational institutions intensifies, meeting the employment and employability expectations of international students in their host country or country of origin has become increasingly important.

Research conducted shows that visa planning and immigration procedures will play an increasingly important role in the decision-making process, as students will not only look for work after graduation, but may also obtain residency in the country of their choice. Countries that promote the arrival and integration of foreign students through employment and immigration initiatives may be more competitive in the market (Verbik \& Lasanowski 2007, p.9).

It is known that in the late 1990s, firstly in the Netherlands and the northern countries, and then in Germany and France, higher education was started to be considered as an export good. There is an intense demand for the countries that have an established academic system and provide education in the English language accepted as the international language of the 21st century. The United States and Great Britain, in particular, take the lead. Nevertheless, based on the data, recent trends clearly show that new directions in the sense of international student mobility are inevitable (De Wit \& Adams, 2010, p. 220-233). Turkey also has significant potential and opportunities to make international students its guests. This study evaluates the latest trends of global student mobility in the world and the current position of Turkey. The opportunities provided by Turquailty, a branding program supported by the Ministry of Commerce, to higher education institutions were also evaluated. In this sense, the study is an up-to-date resource for members of higher education, decision-makers, and policy-makers in this field.

\section{EDUCATION ECONOMICS, INTERNATIONALIZATION AND HIGHER EDUCATION}

In today's world, the easier and faster exchange of information, the economies integrated, and the ease of inter-country mobility, which has become more comfortable compared to the past, have increased internationalization in various fields around the world. With the increase in the demand for higher education worldwide, one of the most affected areas has been the higher education sector. International student mobility is con- sidered as the second dimension of globalization by the Organization for Economic Development and Cooperation (OECD). Various countries are working to attract international students to their countries. In addition to the economic contribution it provides in terms of educational exports, gaining international students provides benefits such as increasing the trained workforce. This situation adversely affects the undeveloped and developing countries where brain drain happens while creating advantages for the countries receiving the migration. Besides, if the students studying abroad return to their countries; as a volunteer cultural ambassador of the state in which they are educated, they also contribute to the development of international social relations.

To Turkey, as a country that the number of students sent abroad every year, and every year it receives from abroad exceeds 50000 in total, this economy gains importance. Likewise, these numbers increase every year. Although the number of students coming from abroad and the number of students going abroad is similar, research has shown that the economic contributions of students coming from abroad and students going abroad are very different from each other. Expenditures of students coming from abroad correspond to about one-sixth of the expenses of students going abroad. The main reason for this situation is the fact that the tuition fees received from international students by universities, especially state universities, are quite limited compared to the fees charged by other schools in the world higher education market (Uslu, 2017, p. 215). On the other hand, when compared with other countries, our country for international students is not yet sufficiently attractive and important problems faced by international students are still not resolved, and the expectations of international students are still not met. It can be shown as an indicator that before the Syrian crisis, the number of students coming to Turkey is lower than the number of students going from Turkey. It is faced with communication problems since the universities in Turkey are not known and introduced enough abroad, opportunities, and facilities provided to students studying in Turkey are not explained enough. Besides the qualities and the number of students studying in Turkey being a separate subject of discussion, graduation rates are low.

According to OECD, the total number of international students in the world was around 800 thousand in 1975 and reached 6 million as of 2014. It is estimated that this number will reach 8 million by 2020 (OECD, 2017). As can be seen in Table 1, The United States is the most preferred country for students, while the United Kingdom comes second. In general, it is possible to observe that English-speaking countries weight in this field. Inevitably, countries that want to compete in this race and want to receive brain drain instead of brain drain should implement significant incentives and produce policies. Different nations can be gained from the situation of the US, 
UK and Germany. Countries that look for the short monetary impact ought to put resources into the modernization and notoriety of the universities to draw in unfamiliar understudies and as the trades of higher educational expenses. In other hand, long haul result searchers expected to give a less expensive educational expenses to draw in far off nations particularly the low pay understudies who have higher limit. These districts ought to ready to choose the best possible worldwide understudies and all the more significantly interface their got ability to contribute and work in the country (Fahlevi, 2015 p.151)

Internationalization in higher education is seen as an issue that improves the quality of universities, and it has the potential to make significant contributions at different levels, especially to the economies of countries, social, cultural, and political fields. For this reason, it is seen that countries which are important actors in their regions and the world or advancing in this direction compete with each other to become an important center of attraction in higher education at the level of internationalization at both student and academic degree and implement different projects with big budgets (Özer, 2017, p. 178). In this field, it should be considered as an essential step that in Turkey, the Turquality concept began to be implemented in the higher education sector.

Table 1. Number of International Students in the Countries in 20172018 (Atlas, 2019)

\begin{tabular}{|c|c|c|c|c|c|}
\hline $\begin{array}{l}\text { Ran- } \\
\text { king }\end{array}$ & $\begin{array}{l}\text { Desti- } \\
\text { nation } \\
\text { Country }\end{array}$ & $\begin{array}{c}\text { Number } \\
\text { of Foreign } \\
\text { Students } \\
(2017)\end{array}$ & $\begin{array}{c}\text { Number } \\
\text { of Foreign } \\
\text { Students } \\
(2018)\end{array}$ & $\begin{array}{c}\text { Change } \\
(\%)\end{array}$ & $\begin{array}{l}\text { Country Sen- } \\
\text { ding Students }\end{array}$ \\
\hline 1 & USA & 1.078 .822 & 1.094 .792 & $+1.48 \%$ & $\begin{array}{c}\text { China } \\
\text { India } \\
\text { South Korea }\end{array}$ \\
\hline 2 & UK & 501.045 & 506.480 & $+1.08 \%$ & $\begin{array}{l}\text { China } \\
\text { USA } \\
\text { Germany }\end{array}$ \\
\hline 3 & China & 442.773 & 489.200 & $+10.49 \%$ & $\begin{array}{c}\text { South Korea } \\
\text { Thailand } \\
\text { Pakistan }\end{array}$ \\
\hline 4 & Australia & 327.606 & 371.885 & $+13.52 \%$ & $\begin{array}{l}\text { China } \\
\text { India } \\
\text { Nepal }\end{array}$ \\
\hline 5 & Canada & 312.100 & 370.710 & $+18.78 \%$ & $\begin{array}{c}\text { China } \\
\text { India } \\
\text { South Korea }\end{array}$ \\
\hline 6 & France & 323.933 & 343.386 & $+6.01 \%$ & $\begin{array}{l}\text { Morocco } \\
\text { Algeria } \\
\text { China }\end{array}$ \\
\hline 7 & Russia & 296.178 & 313.089 & $+5.71 \%$ & $\begin{array}{l}\text { Kazakhstan } \\
\text { China } \\
\text { Uzbekistan }\end{array}$ \\
\hline 8 & Germany & 251.542 & 265.484 & $+5.54 \%$ & $\begin{array}{l}\text { China } \\
\text { India } \\
\text { Russia }\end{array}$ \\
\hline 9 & Japan & 171.122 & 188.384 & $+10.09 \%$ & $\begin{array}{c}\text { China } \\
\text { Vietnamese } \\
\text { Nepal }\end{array}$ \\
\hline 10 & Turkey & 108.076 & 148.000 & $+44.4 \%$ & $\begin{array}{c}\text { Syria } \\
\text { Azerbaijan } \\
\text { Turkmenistan }\end{array}$ \\
\hline
\end{tabular}

As can be seen in Table 2, The largest number of international students in circulation in the world belongs to China, India, and Korea, respectively. The countries that send the highest number of international students are Asian countries from the past to the present.

Table 2. Countries with the Largest Number of International Students in Circulation (Atlas, 2019)

\begin{tabular}{|c|c|c|c|}
\hline Ranking & Student's Country & $\begin{array}{c}\text { Number of } \\
\text { Students in } \\
\text { Circulation }\end{array}$ & $\begin{array}{c}\text { Ratio to Total } \\
\text { Number of Students } \\
\text { in Circulation }\end{array}$ \\
\hline 1 & China & 694.400 & $9,26 \%$ \\
\hline 2 & India & 189.500 & $2,53 \%$ \\
\hline 3 & South Korea & 123.700 & $1,65 \%$ \\
\hline 4 & Germany & 117.600 & $1,57 \%$ \\
\hline 5 & Turkey & 110.000 & $1,47 \%$ \\
\hline 6 & Saudi Arabia & 62.500 & $0,29 \%$ \\
\hline 7 & France & 62.400 & $0,28 \%$ \\
\hline 8 & USA & 58.100 & $0,26 \%$ \\
\hline 9 & Malaysia & 55.600 & $0,25 \%$ \\
\hline 10 & Vietnamese & 53.800 & $0,22 \%$ \\
\hline
\end{tabular}

When the ratio of international students hosted by countries to their higher education population is examined, it is possible to observe the weight of the English-speaking countries. As of 2018, Australia ranked first in this area, with $32 \%$ of its students from international students, followed by the UK and Canada. As can be seen in Table 3, New Zealand which is another English-speaking country ranks 4th; and France is followed by the Netherlands where English is widely spoken country.

Table 3. Ratio of Students Hosted by Countries to Total Number of Students (Atlas, 2019)

\begin{tabular}{|c|c|c|c|}
\hline \multirow{2}{*}{ Ranking } & \multirow{2}{*}{ Country } & \multicolumn{2}{|c|}{$\begin{array}{r}\text { The ratio of International Stu- } \\
\text { dents to Total Students }\end{array}$} \\
\cline { 3 - 4 } & & 2017 & 2018 \\
\hline 1 & Australia & $23,8 \%$ & $32 \%$ \\
\hline 2 & United Kingdom & $21,1 \%$ & $21 \%$ \\
\hline 3 & Canada & $15,2 \%$ & $18,3 \%$ \\
\hline 4 & New Zeland & $15 \%$ & $15,2 \%$ \\
\hline 5 & France & $12,4 \%$ & $12,8 \%$ \\
\hline 6 & Netherlands & $11,4 \%$ & $10,7 \%$ \\
\hline 7 & Finland & $10,6 \%$ & $10,4 \%$ \\
\hline 8 & Germany & $8,7 \%$ & $9,5 \%$ \\
\hline 9 & Swedish & $8,7 \%$ & $10,4 \%$ \\
\hline 10 & Spain & $6,1 \%$ & $7 \%$ \\
\hline 11 & Russia & $5,7 \%$ & $7,1 \%$ \\
\hline 12 & USA & $5,3 \%$ & $5,5 \%$ \\
\hline 13 & Japan & $4,7 \%$ & $5,1 \%$ \\
\hline 14 & Turkey & $2 \%$ & $2.2 \%$ \\
\hline 15 & China & $1,1 \%$ & $1,1 \%$ \\
\hline & & & \\
\hline
\end{tabular}

As of 2018, 22\% of the international students in circulation are hosted by the USA, while the United Kingdom and China follow this country with a share of $10 \%$. 
Table 4. Most Preferred Countries by Students (Atlas, 2019)

\begin{tabular}{|c|c|c|c|}
\hline \multirow{2}{*}{ Ranking } & \multirow{2}{*}{ Country } & \multicolumn{2}{|c|}{ Percentage of Preference } \\
\cline { 3 - 4 } & & 2017 & 2018 \\
\hline 1 & USA & $24 \%$ & $22 \%$ \\
\hline 2 & United Kingdom & $11 \%$ & $10 \%$ \\
\hline 3 & China & $10 \%$ & $10 \%$ \\
\hline 4 & Australia & $10 \%$ & $7 \%$ \\
\hline 5 & France & $7 \%$ & $7 \%$ \\
\hline 6 & Canada & $7 \%$ & $7 \%$ \\
\hline 7 & Russia & $6 \%$ & $6 \%$ \\
\hline 8 & Germany & $6 \%$ & $5 \%$ \\
\hline 9 & Others & $23 \%$ & $25 \%$ \\
\hline
\end{tabular}

The importance of internationalization in higher education and taking steps to attract international students to the country has entered the list of priorities with 10 . Turkey's Development Plan. Considering the economic, social, cultural, and academic contributions of internationalization in higher education, it is evident that Turkey as a valuable player in both its region and the world should not leave the field out. Increasing the number of international students by $75 \%$ over the last decade, Turkey has entered the list of the countries that host the largest number of international students in the world.

It is observed that the most prominent source countries in the international student supply from past to present are Asian countries, especially China, India, and South Korea. But when the country of origin of students coming to study in Turkey is examined, it will be seen that there is relatively little involvement from the Far East and European countries. It is possible to say that Turkey obtained international students from neighboring countries and the regions where the geographical and cultural closeness of our countries exists. Therefore, the nature of the global student market in Turkey is different from those of many developed countries. This particular case is the most fundamental evidence that Turkey's both universities and government agencies must have their roadmap and strategies. Also, the necessity of country-specific research is another issue that needs to be emphasized. As can be seen in Figure 1, Turkey receives the largest number of international students from Syria. The main reasons for the increase in the number of Syrian students in recent years are the war experience of the neighboring country and the resulting political instability. Syria is followed by Azerbaijan, with more than 148 thousand students. Among the top 10 countries sending students to Turkey, only two countries, Germany and Bulgaria, are European countries. It can be predicted that a portion of international students from Germany to Turkey might be Turks having German citizenship. In this context, we can say that Turkey welcomes the relatively small number of students from developed countries and receives little share of the Asian countries with the most substantial weight in the international student sector.

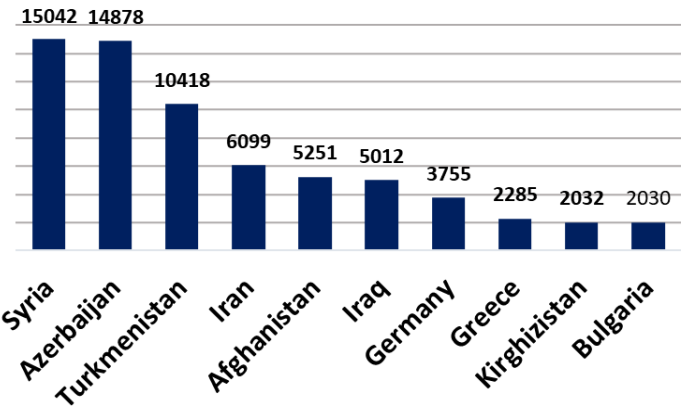

Figure 1. Countries Sending the Largest Number of Students to Turkey

It is an urgent necessity to make policies on the Asian and European countries that sends a very small number of students to Turkey. There is a need for promotional processes that emphasize the main factors, such as the cost of living and education in Turkey is lower than in many other countries. To produce accurate and complete information about universities in Turkey, effective public diplomacy should be implemented (Özoğlu, Gur, \& Coşkun, 2012). Interpreting international students as educational exports and including them in the scope of Turquality is an important step taken in this field in terms of government incentives. Thus, foundation universities will have the opportunity to strengthen their promotion and marketing activities to attract more international students.

As seen in Figure 2, the number of international students studying in Turkey tends to increase every year. The upward trend, which remained stable until 2008, has accelerated since this year. At this point, the studies initiated by YÖK are critical. It should not be ignored that the Syrian crisis also had an impact on the increase in the number of international students.

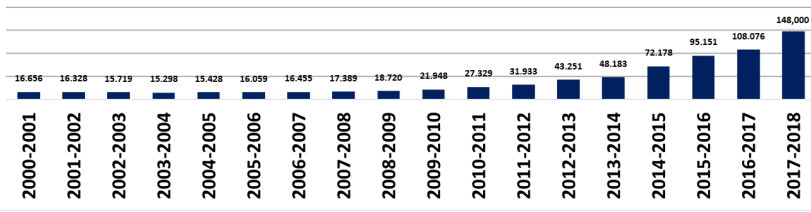

Figure 2. Number of International Students in Turkey by Years

According to the OECD's Education at a Glance report, in 2013, the average number of internationally registered students in undergraduate or equivalent programs was $6 \%$, while the average of internationally registered students in master's or equivalent programs was $14 \%$ and $24 \%$ in doctorate. (OECD, 2017). It can be said that in Turkey, this trend was gained by the year 2017. In particular, there was an increase in the number of international doctoral students in Turkey, but there is still a significant lack in this area. The development of policies to attract graduate students is essential. The introduction, encouragement, and continuous improvement of doctoral programs, the development of program infrastructures, and the support of industrial collaborations will pave the way for our country to meet the faculty needs. 
In parallel with the developments in the world in the field of internationalization, the Turkish higher education system has taken important steps in recent years. It has begun to reap the fruits of these steps. The main initiatives carried out in this field in Turkey are as follows:

- Bologna Process,

- TURQUAS Project,

- Erasmus and Erasmus+ programs,

- Türkiye Scholarships, Mevlana Exchange Program,

- Joint Diploma programs,

- Project-based International Exchange Program,

- YABSİS Project,

- School Recognition and Accreditation Regulation,

- Extending the Duration of Stay of Ph.D. Students in Turkey After Graduation,

- YOK started to provide scholarships to international students,

- Abolition of the quota limit for foreign students

- Opening of Turquality to Education Sector

\section{TURQUAILITY'S CONTRIBUTIONS TO THE INTERNATIONAL BRANDING PROCESS}

In terms of the perception of consumers demanding various products and services; It can be defined as the process of creating images with differentiated, unique features, and personalities. At the same time, one of the main objectives of the branding process is to ensure the identifiability and recognition of the brand. The branding process is a strategic process that requires serious long-term investment and planning (Deniz, 2010, p. 34). Branding has become one of the most important targets for all enterprises and institutions in the globalization environment where competition is increasing in terms of price, time, quality, and innovation.

It should be noted that the benefit of the brand is not only for businesses. The globalization of brands makes significant contributions to the power of the country and the national economy. It should not be ignored that many strong brands such as Coca-Cola, Apple, and Microsoft, take part in the strength of the US economy. With a successful branding strategy, it is possible to become an international brand in all kinds of products and services (Ries, 2001, p. 116). When we look at the higher education sector, it is possible to say that the image and reputation of US universities are quite strong. Universities such as MIT, Stanford, Harvard, and Yale are strong brands recognized by the world.

Similarly, it is not a coincidence that England, which has world-renowned universities such as Oxford and Cambridge, is among the countries that are most in-demand by international students. There is no doubt that these countries are very good at promoting their higher edu- cation ecosystems alongside the brand value of their universities. It should not be ignored that branding is also a promise.

The feature of the Turquality program is that it is the world's first state-sponsored international branding program. Turquality has the distinction of being a program that separates the value-added products in the internal and external competition process and contributes financially and managerially to become a world brand. Turquality aims to operate a systematic quality management system in all processes, from product design to sale. The Turquality program is described on its website as follows:

TURQUALITY ${ }^{\oplus}$ offers a wide range of services to businesses that have a competitive edge and are capable of branding. These services range from the products manufactured by the enterprises to the marketing activities, from sales to after-sales. Turquality works to develop managerial know-how to cover all of the processes, to develop institutional features, and to transform businesses into a global player with their brands in international market markets. Turquality is the first and only state-sponsored branding program created to create a positive image of Turkish goods through the brands mentioned above. At the heart of the TURQUALITY ${ }^{\odot}$ Program, apart from the classical export supports, is to contribute to the branding goals of the enterprises rather than simply increasing the volume of exports (Turquality, 2019)." Launched in 2004, the program first provided incentives for branding in the textile and apparel sectors. Today, these supports have spread to various industries. As of 2019, two foundation universities were included in the process, and the higher education sector started to be supported.

Turquality creates a two-dimensional effect as it promotes the brand of our country by increasing brand awareness and creating a high-quality product range besides the contribution that companies make to brand value. Each brand in this project increases Turquality's influence in overseas markets. Thus it provides a competitive advantage for exporters (Akın, 2018, p. 172).

Turquality confirms that Turkish enterprises manage their business processes within the framework of specific standards. Program objectives are listed as follows (Turquality, 2019):

- To play a role in promoting branding by providing financial resources to companies with the brand potential to become a global brand,

- To provide strategy, operations, organization, and technology consultancy support for the development of businesses and brands to create global Turkish brands,

- To strengthen the total human resources through training support provided to the management units of the enterprises within the scope of the program, 
- To ensure the creation and promotion of a positive image of Turkish goods abroad through communication and promotional activities,

- To increase the brand potential and brand awareness of Turkish enterprises,

- To provide information and communication support for Turkish enterprises to take action within the knowledge of the market,

- To be an incubator and catalyst for selected Turkish brands.

Operational maturity levels of enterprises applying to participate in the program are evaluated in detail based on ten different criteria. Companies are expected to have a strategy and a systematic implementation tradition in all of the following topics:

- Strategic Planning and Corporate Performance

- Financial Performance

- Operations Management

- Brand Management and Performance

- Digitalization

- New Product Development (Innovation)
- Marketing Sales and Trade Management

- Corporate Governance

- Human resources

- Information technologies

It is possible to divide the support provided under the program into Financial and Non-Financial Supports.

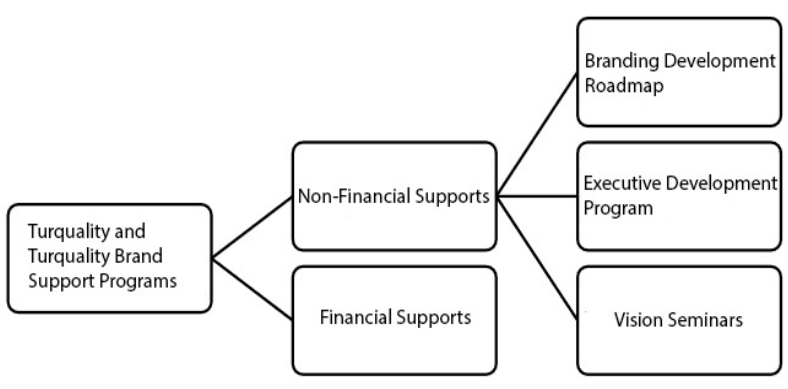

Figure 3. Turquality Support Types (Turquality, 2019)

The following expenses of the firms that apply by providing the necessary documents and which have been pre-evaluated by the TURQUALITY ${ }^{\odot}$ Program management consultancy firm and decided to receive TURQUALITY ${ }^{\circledast}$ Supports by the Ministry of Commerce are supported by fifty percent. If the companies applying the

Table 5. Turquality Program Financial Supports (Turquality, 2019)

\begin{tabular}{|c|c|c|c|c|}
\hline \multirow{2}{*}{ Support Type } & \multirow{2}{*}{$\begin{array}{l}2017 \text { Support } \\
\text { Limit }\end{array}$} & $\begin{array}{l}2018 \text { Support } \\
\text { Limit }\end{array}$ & $\begin{array}{l}2019 \text { Support } \\
\text { Limit }\end{array}$ & \multirow{2}{*}{ Length / Piece } \\
\hline & & $\begin{array}{l}(\mathrm{CPI}+\mathrm{DOMESTI}- \\
\quad \mathrm{C}-\mathrm{PPI}) / 2\end{array}$ & $\begin{array}{l}(\mathrm{CPI}+\mathrm{DOMESTI}- \\
\mathrm{C}-\mathrm{PPI}) / 2\end{array}$ & \\
\hline $\begin{array}{l}\text { Patent, utility model and industrial design registration, trade- } \\
\text { mark registration / renewal / protection }\end{array}$ & unlimited & unlimited & unlimited & 5 years per target market \\
\hline Promotional expenses & unlimited & unlimited & unlimited & 5 years per target market \\
\hline Store rent & $\begin{array}{l}\text { unlimited (for up } \\
\text { to } 50 \text { stores at the } \\
\text { same time) }\end{array}$ & $\begin{array}{l}\text { unlimited (for up } \\
\text { to } 50 \text { stores at the } \\
\text { same time) }\end{array}$ & $\begin{array}{l}\text { unlimited (for up } \\
\text { to } 50 \text { stores at the } \\
\text { same time) }\end{array}$ & 5 years per target market \\
\hline $\begin{array}{l}\text { Store basic installation / decoration / concept architectural } \\
\text { expenses }\end{array}$ & $\begin{array}{l}800.000 \text { TL / store } \\
\text { (Shops with Rent } \\
\text { Support) }\end{array}$ & $\begin{array}{l}909.560 \mathrm{TL} / \\
\text { (Shops with Rent } \\
\text { Support) }\end{array}$ & $\begin{array}{l}1.154 .000 \mathrm{TL} / \\
\text { (Shops with Rent } \\
\text { Support) }\end{array}$ & 5 years per target market \\
\hline $\begin{array}{l}\text { Office, warehouse, showroom, after-sales service, aisle/shelf / } \\
\text { decorated corner rent }\end{array}$ & unlimited & unlimited & unlimited & 5 years per target market \\
\hline $\begin{array}{l}\text { Office, warehouse, showroom, after-sales service, aisle / shelf } \\
\text { / decorated corner foundation installation / decoration / } \\
\text { concept architectural expenses }\end{array}$ & $800.000 \mathrm{TL} /$ unit & $909.560 \mathrm{TL} /$ unit & 1.154.000 TL/ unit & 5 years per target market \\
\hline $\begin{array}{l}\text { Market entry documents, certification, licensing, testing / } \\
\text { clinical testing }\end{array}$ & 2.000.000 TL / year & $\begin{array}{l}2.273 .900 \mathrm{TL} / \\
\text { year }\end{array}$ & $\begin{array}{l}2.887 .000 \mathrm{TL} \\
\text { / year }\end{array}$ & 5 years per target market \\
\hline $\begin{array}{l}\text { Franchise decoration / installation / concept architectural } \\
\text { expenses }\end{array}$ & $\begin{array}{l}400.000 \mathrm{TL} / \text { store } \\
\text { (for up to } 100 \\
\text { stores) }\end{array}$ & $\begin{array}{l}454.780 \text { TL / store } \\
\text { (for up to } 100 \\
\text { stores) }\end{array}$ & $\begin{array}{l}577.000 \mathrm{TL} / \text { store } \\
\text { (for up to } 100 \\
\text { stores) }\end{array}$ & 5 years per target market \\
\hline \multirow[t]{2}{*}{ Franchise rent } & \multirow{2}{*}{$\begin{array}{l}800.000 \text { TL / Year } \\
\text { / Store (Max } 100 \\
\text { stores) }\end{array}$} & \multirow{2}{*}{$\begin{array}{c}909.560 \text { TL / Year } \\
\text { / Store (Max } 100 \\
\text { stores) }\end{array}$} & \multirow{2}{*}{$\begin{array}{c}\text { 1.154.000 TL/ Year } \\
\text { / Store (Max } 100 \\
\text { stores) }\end{array}$} & $\begin{array}{l}2 \text { years for the same store } \\
\text { (target market based) }\end{array}$ \\
\hline & & & & 5 years per target market \\
\hline $\begin{array}{l}\text { Consultancy for establishing institutional infrastructure } \\
\text { (ANNEX 13A) }\end{array}$ & \multirow[t]{2}{*}{ 2.000.000 TL / year } & \multirow{2}{*}{$\begin{array}{l}\text { 2.273.900 TL / } \\
\text { year }\end{array}$} & \multirow{2}{*}{$\begin{array}{l}2.887 .000 \mathrm{TL} / \\
\text { year }\end{array}$} & first 5 years \\
\hline Consultations exclusively for target markets (ANNEX 13B) & & & & 5 years per target market \\
\hline Employment & $\begin{array}{l}\text { unlimited (up to } \\
10 \text { people at the } \\
\text { same time) }\end{array}$ & $\begin{array}{l}\text { unlimited (up to } \\
10 \text { people at the } \\
\text { same time) }\end{array}$ & $\begin{array}{l}\text { unlimited (up } \\
\text { to } 10 \text { people at } \\
\text { the same time) }\end{array}$ & first 5 years \\
\hline Market research and reports & unlimited & unlimited & unlimited & 5 years per target market \\
\hline Fair & unlimited & unlimited & unlimited & unlimited \\
\hline Storage Service & unlimited & unlimited & unlimited & 5 years per target market \\
\hline Development Roadmap Study & $800.000 \mathrm{TL}$ & $800.000 \mathrm{TL}$ & $800.000 \mathrm{TL}$ & only for 1 time \\
\hline
\end{tabular}


same application process cannot qualify for Turquality support, they may be included in the incentive program within the scope of Brand Support and may receive more limited cash supports. Non-financial supports are the educational and research supports provided to the human resources of the firms.

The preliminary examination of the enterprises applying to the program is carried out by one of the six companies authorized by the Ministry of Commerce. These companies are Deloitte, Ernst and Young, McKinsey, PricewaterhouseCoopers (PWC), Boston Consulting Group, and KPMG. The same companies have the authority to provide consultancy services for the development of the Branding Development Roadmap. The company should not have worked with the company from which it will receive consultancy from the Turquality process.When the general structure of the program and the supports provided are examined, it is possible to say that the advantages of this program to universities in a globalizing educational economy environment are quite diverse and very important. However, although there are many ways that higher education institutions in our country have to take in terms of branding of universities, unfortunately, the issue of branding is rarely mentioned among the specific needs of today's universities. Moreover, the idea of branding in higher education in our country is not sufficiently widespread. There are various concerns about the applicability of the concept of branding in the higher education sector and the value that branding will create for universities (Nardalı \& Tanyeri, 2011, p. 316). In the process of branding, the fact that universities are treated as commercial institutions is one of the most critical questions. However, it is a fact that the perception about university plays an important role both in employer preferences and student preferences in social life.

Turkey's economic relations with other countries are developed with the contribution of Turquality, and thanks to that, many Turkish companies and brands will continue to make investments and carry out commercial activities in foreign countries and various industries. The fact that higher education institutions assume responsibility as actors in this process will not only increase the economic capacity of the country but also contribute to the development of the country's image and reputation.

In contrast to classical diplomacy focusing on international relations, public diplomacy practices that focus on both culture and the construction of individual and institutional dialogue are strengthened with programs such as Turquality. Public relations, advertising, lobbying, media applications, and digital media applications play a role in the formation of soft power in public diplomacy practice (Akın, 2018, p. 213). In addition to public diplomacy and cultural contributions, it is clear that international students create an economic size that cannot be ignored. Turkey has the potential to take a bigger share from the growing international student pie in the world. Scholarships for Africa should be encouraged and strategic research should be conducted for students from countries with high economic power (Sağiroğlu, 2015 p. 42.)

\section{CONCLUSION AND EVALUATION}

The multidimensional effects of globalization have led to the emergence of internationalization in the world of higher education. The OECD considers international student circulation as the second dimension of globalization. Since the nineties, higher education is regarded as an export commodity by various countries and countries are developing policies in this field Countries struggling to get a share of world trade also follow strategies in the education sector. While millions of students in the world participate in the circulation, the primary source is the far-east countries, especially China, and the most sought-after countries are the developed countries, especially the USA. Welcoming nearly 150 thousand international students, Turkey has taken its place among the top ten countries in this area. The increase in the number of international students studying in Turkey is mainly thanks to the measures taken and developed strategies by the HEC. However, a large number of students from Syria came to our country, and this was also important in increasing this number. Turkey as a country among the countries that have hosted the largest number of international students, has even dynamics that are quite different from the general structure of international roaming. Worldwide, China and other far-eastern countries are the ones sending the largest number of students abroad, but Turkey receives a very small number of students from these countries. Students coming to Turkey, except the ones from Syria, are from the countries that Turkey has cultural, diplomatic, and geographical proximity. In this sense, it can be said that there is a lack in both public diplomacy activities of Turkey and the promotion of its universities and higher education field of the country. It is necessary to raise brand awareness to the highest level and to create reliable and sustainable images. It is clear that the opportunities provided by studying at a Turkish university should be conveyed to target audiences through a better communication plan. In this sense, foundation universities also have important duties. However, it is clear that it is not easy to bear the financial burden of doing marketing communication studies abroad. The opening of Turquality, the world's first state-sponsored branding program, to the education sector can be seen as a very important opportunity that universities have achieved. Turquality provides a wide range of branding supports by measuring the institutional performance of higher education institutions with various criteria.

discussion group must respond to all members of that same group within a two week time period. After careful analysis of the transcripts from this virtual conference 
seminar, it is apparent that equal participation on-line requires careful support and planning with some rules concerning attending and responding to other participants.

\section{REFERENCES}

Akin, M. A. (2018). Nation Marking as a Tool for Public Diplomacy: The Case of Turquality. Istanbul: Maltepe University.

Altbach, P. G. (1998). Comparative Higher Education: Knowledge of the University, and Development. Comparative Education Research Center, The University of Hong Kong.

Arkalı Olcay, G., \& Nasır, V. (2016). Internationalization of Higher Education: Top Student Perspective Overview of Area Countries and Turkey from 99-13 years. Journal of Higher Education and Science, 288-296.

Atlas, P. (2019, Ağustos 1). Research and Insights. Retrieved from Institute of International Education: https://www.iie.org/ en/Research-and-Insights/Project-Atlas/Explore-Data/ Current-Infographics

Choudaha, R. (2017) Three waves of international student mobility (1999-2020), Studies in Higher Education, 42:5

De Wit, H, \& Adams, T. (2010). Global competition in higher education: A comparative study of policies, rationales, and practices in Australia and Europe. In Higher education, pol$i c y$, and the global competition phenomenon (pp. 219-233). New York: Palgrave Macmillan.

Deniz, E. (2010). Branding and Advertising . İstanbul: Kum Saati Publications.

Fahlevi, H. (2015) Economic Implication of International Student Mobility For Host Countries - Evidences from Western Countries. International Student Symposium

Knight, J. (1994). Internationalization: Elements and Checkpoints. Ottawa: Canadian Bureau for International Education (CBIE).

Nardalı, S., \& Tanyeri, M. (2011). Branding in Higher Education. Journal of Faculty of Business, Volume 12, Number 2, 309319.

OECD. (2017). Education at a Glance 2017: OECD Indicators. Paris: OECD Publishing.

Özer, M. Last Fifteen Years of Higher Education Internationalization in Turkey. Journal of Higher Education and Science, 177-184.

Özoğlu, M., Gur, B. S., \& Coşkun, İ. (2012). International Students in Turkey in the light of Global Trends. SETA.

Ries, A. L. (2001). 11 invariable rules of brand building on the Internet. MediaCat Books.

Sağıroğlu, A. Z. (2015). International Student Trends in the World and in Turkey. International Student Symposium

Turquality. (2019, 830$)$. Retrieved from https://www.turquality. com

Uslu, B. (2017). Turkey Centered Economic Implications of International Student Mobility. 12th International Congress on Educational Administration (pp. 213-216). Ankara: Pegem. 